\title{
Snow Chemistry at Mukteshwar in Central Himalayan Region of India
}

\author{
Bablu Kumar', Gupta GP1, Sudha Singh ${ }^{1}$, Lone FA ${ }^{2}$ and Kulshrestha UC ${ }^{*}$ \\ ${ }^{1}$ School of Environmental Sciences, Jawaharlal Nehru University, New Delhi 110067, India \\ ${ }^{2}$ Centre for Climate Change, Mountain and Agriculture, SKUAST, Shalimar, Srinagar, 191123, Jammu \& Kashmir, India
}

\begin{abstract}
The present study reports snow chemistry and source apportionment at Mukteshwar in central Himalayan region of India during winter 2012-13. In this study, fresh snowfall samples were collected at Mukteshwar during winter season of 2012-13. The results showed that the $\mathrm{pH}$ of the snowmelt samples ranged from 5.47 to 7.95 with an average of 6.37 indicating alkaline nature of precipitation which is similar to the range reported. The concentration of ions followed the following order- $\mathrm{Ca}^{2+}>\mathrm{Cl}^{-}>\mathrm{Na}^{+}>\mathrm{SO}_{4}^{2-}>\mathrm{HCO}_{3}^{-}>\mathrm{NH}_{4}^{+}>\mathrm{NO}_{3}^{-}>\mathrm{Mg}^{2+}>\mathrm{K}^{+}>\mathrm{F}^{-}$. Very high concentration of $\mathrm{Ca}^{2+}$ indicated the dominance of crustal sources. Source fraction calculations revealed that crustal, marine and anthropogenic sources contributed $40 \%, 38 \%$ and $22 \%$ ionic components in snowmelt, respectively. Since, Mukteshwar is remote site as compared to Delhi, values of $\mathrm{NO}_{3}^{-}$were compared with the $\mathrm{NO}_{3}^{-}$reported in the precipitation (rain water) of Delhi as $\mathrm{NO}_{3}^{-}$is an indicator of vehicular pollution in urban areas. Such comparison of $\mathrm{NO}_{3}{ }^{-}$values suggested that though Mukteshwar precipitation had 1/3 of $\mathrm{NO}_{3}^{-}$in precipitation as compared to Delhi, but considering it as a small town, precipitation at Mukteshwar is significantly influenced vehicular sources possibly due to Long Range Transport (LRT) of pollution.
\end{abstract}

Keywords: Himalaya; Precipitation; Vehicular pollution; $\mathrm{NO}_{3}$; Crustal sources

\section{Introduction}

Air pollution is considered as one of the major environmental challenges. Huge amount of air pollutants is injected into the atmosphere due to rapid urban and industrial growth during past few decades. South East and South Asian are the major air pollution emitters due to rapidly increasing energy demand for their fast growing economy. Among south Asian countries, Indian emissions are significant. After China, India is the second biggest emitter of $\mathrm{SO}_{2}$ in Asia [1]. However, the levels of gas like $\mathrm{SO}_{2}$ are quenched by atmospheric dust in India resulting in very low ambient $\mathrm{SO}_{2}[2,3]$. Nevertheless, emissions of atmospheric aerosols and gaseous pollutants have caused the problems of acid deposition, ozone depletion, climate change and monsoon modification etc. [4-6]. Once emitted, most of these pollutants are scavenged by removal processes. Wet deposition is one of the most effective deposition processes of airborne pollutants.

Long term study of wet deposition can be used to notice the changes in oxides of $\mathrm{N} \& \mathrm{~S}$ content thereby relating to coal \& petroleum energy consumption patterns. Hence, rain and snow chemistry become very important to know the sources of pollution and their possible effects on ecosystems and environment. Precipitation chemistry in general, provides information about the deposition fluxes of various air pollutants to different ecosystems. Due to its significance, snowfall chemistry has been studied extensively throughout the world [7-14]. Fresh snow chemistry in Himalaya ranges had shown relatively low concentration of air borne pollutants are representative of remote site $[9,11,15]$. The ionic content in Himalayan snow is highly affected by the impact of long range transport of anthropogenic sources of air pollutants [16]. Snow chemistry at Shanghai in China suggested that fossil fuel combustion and biomass burning is the major source of air pollution [14].

Acid deposition, a serious threat to terrestrial, aquatic and marine ecosystem has been studied comprehensively at various places in North America, Europe, Japan and other countries of the world [2,17-19]. Acidic precipitation is determined primarily by the interaction of acidic and basic species in the atmosphere. Acidic species are dominated by $\mathrm{SO}_{2}$ and $\mathrm{NO}_{\mathrm{x}}$ which is precursor of $\mathrm{H}_{2} \mathrm{SO}_{4}$ and $\mathrm{HNO}_{3}$ respectively which are mainly emitted by fossil fuel combustion. On the other hand, alkaline species $\left(\mathrm{Ca}^{2+}, \mathrm{Mg}^{2+}\right.$ and $\left.\mathrm{NH}_{4}^{+}\right)$help in enhancing $\mathrm{pH}$ of precipitation. The main source of these species is atmospheric dust which is made up of carbonates and bicarbonates of Ca and $\mathrm{Mg}[2,3,20]$. Unlike North America and Europe, it is interesting that higher $\mathrm{pH}$ of precipitation is reported in India even at higher $\mathrm{SO}_{4}^{2-}$ concentration which might be due to huge amount of dust in the atmosphere [3].

In India, several studies have been reported on rain chemistry mostly in urban areas [2,21-26] with few studies from rural sites [2730]. The detailed and updated studies on fresh snowfall chemistry are even rare in rural areas of Himalayan region of India [16,31,32]. Hence, this study was carried out to fill this knowledge gap about the chemical characteristics of snow in central Himalaya by selecting Mukteshwar as a rural representative site. The present study also focuses on quantification of relative contributions of marine and non-marine sources during winter season. Further, non-marine fractions have been quantified into crustal associated and anthropogenic sources. An attempt has been also made to highlight the extent of influence of vehicular pollution in urban area like Delhi vs. remote area like Mukteshwar by considering $\mathrm{NO}_{3}^{-}$concentration as an indicator of vehicular pollution.

\section{Materials and Methods}

\section{Sampling site}

Mukteshwar is located at $29.47^{\circ} \mathrm{N} 79.64^{\circ} \mathrm{E}$ in Nainital district of Uttarakhand state of India (Figure 1). It is situated in the Kumaon Hills of central Himalaya at an altitude of 2286 meters. It lies approx. 51 $\mathrm{km}$ NE of Nainital city, $51 \mathrm{~km}$ from Nainital, $72 \mathrm{~km}$ from Haldwani and $395 \mathrm{~km}$ from Delhi city. Mukteshwar is rich in scenic beauty,

*Corresponding author: Kulshrestha UC, School of Environmental Sciences, Jawaharlal Nehru University, New Delhi 110067, India, Tel: 981-061-1857; E-mail: umeshkulshrestha@gmail.com

Received June 28, 2015; Accepted August 03, 2015; Published August 07, 2015

Citation: Kumar B, Gupta GP, Singh S, Lone FA, Kulshrestha UC, et al. (2015) Snow Chemistry at Mukteshwar in Central Himalayan Region of India. Mod Chem appl 3: 160. doi:10.4172/2329-6798.1000160

Copyright: ( $) 2015$ Kumar B, et al. This is an open-access article distributed under the terms of the Creative Commons Attribution License, which permits unrestricted use, distribution, and reproduction in any medium, provided the original author and source are credited. 


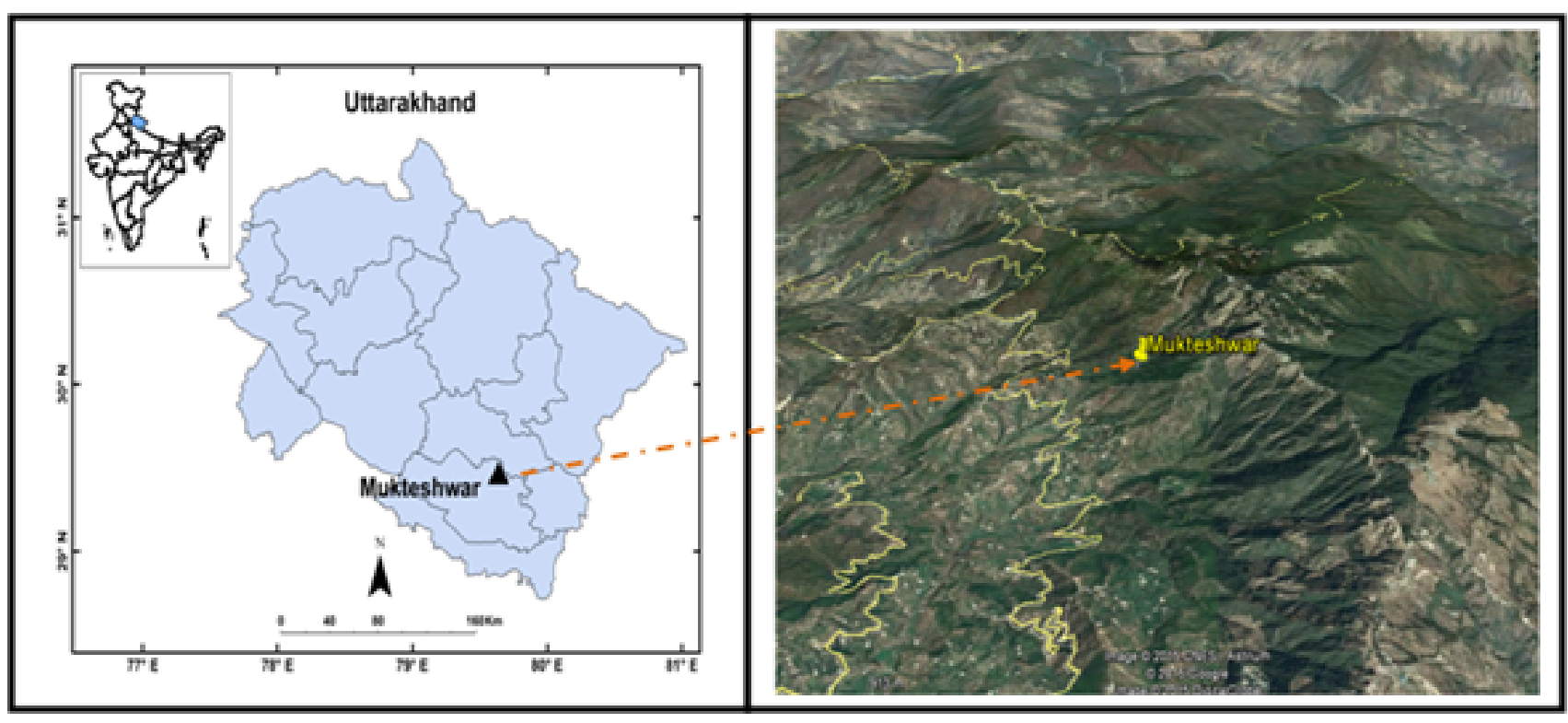

Figure 1: Map of the sampling site.

with magnificent views of the central Himalayas. It is one of the most famous tourist spots in north India which receive domestic as well as foreign tourists every year. The mean minimum temperature in this village ranges from $-5^{\circ} \mathrm{C}$ to $0^{\circ} \mathrm{C}$ during January whereas the mean maximum temperature ranges from $25^{\circ} \mathrm{C}$ to $30^{\circ} \mathrm{C}$ during the month of June. There are no any major industrial units around this site. Most of the people use biomass as a source of energy for domestic heating and cooking purposes. The major sources of air pollution at this site include vehicular pollution used for tourist activities and emissions from agricultural activities.

\section{Collection of snowfall samples}

Fresh snowfall samples were collected with the help of plastic trays (30 cm diameter) on event basis during winter season of 2012-2013. Generally, winter season spreads between November and February but the site receives maximum snowfall during December and January. The tray was washed properly with high quality deionized water and dried before collection of snowfall. Sampler was placed at $\sim 2 \mathrm{~m}$ height above the ground level. The collector tray was kept outside just before the start of snowfall and was removed immediately after snowfall to avoid contamination. In order to cover entire Mukteshwar area, the collection was done at five points at same time on the day of snowfall event. These points are located at around $100 \mathrm{~m}$ distance between each point. Fresh snowfall samples deposited on tray were transferred into pre-cleaned polypropylene bottles using polyethylene gloves. These samples were stored in the refrigerator at the site which was later transferred to the laboratory within 15 days from the collection period. Samples were later processed for analysis of $\mathrm{pH}$, Electrical Conductivity (EC) and major ions.

\section{Analysis of samples}

The collected samples were brought to the laboratory and analysed for major anions, cations, $\mathrm{EC}$ and $\mathrm{pH}$. Determination of major cations $\left(\mathrm{Na}^{+}, \mathrm{NH}_{4}^{+}, \mathrm{K}^{+}, \mathrm{Ca}^{2+}\right.$ and $\left.\mathrm{Mg}^{2+}\right)$ and major anions $\left(\mathrm{F}^{-}, \mathrm{Cl}^{-}, \mathrm{NO}_{3}^{-}\right.$and $\mathrm{SO}_{4}^{2-}$ ) were performed by using ion chromatography (Metrohm 883 Basic IC Plus). Metrosep A SUPP 4, 250/4.0 column and an eluent of $1.8 \mathrm{mmol} / \mathrm{L} \mathrm{Na}_{2} \mathrm{CO}_{3}$ and $1.7 \mathrm{mmol} / \mathrm{L} \mathrm{NaHCO}_{3}$ at a flow rate of 1.0 with Metrohm suppressor technique were used for determination of anions. While Metrosep C4-100/4.0 column and an eluent of 1.7 $\mathrm{mmol} / \mathrm{L}$ Nitric acid and $0.7 \mathrm{mmol} / \mathrm{L}$ Dipicolinic acid at a flow rate of 0.9 without suppressor was used for determination of cations. $\mathrm{HCO}_{3}$ was determined by using $0.0025 \mathrm{~N} \mathrm{H}_{2} \mathrm{SO}_{4}$ [33].

\section{Quality analysis}

Quality control and Quality Assurance (QA/QC) of chemical analysis was performed by checking ion balance and conductivity balance $[24,34,35]$. A significant correlation $\left(\mathrm{R}^{2}=0.81\right)$ was found between sum of anions $\left(\mathrm{F}^{-}, \mathrm{Cl}^{-}, \mathrm{NO}_{3}^{-}, \mathrm{SO}_{4}^{2-}\right.$ and $\left.\mathrm{HCO}_{3}^{-}\right)$and sum of cations $\left(\mathrm{Na}^{+}, \mathrm{NH}_{4}^{+}, \mathrm{K}^{+}, \mathrm{Ca}^{2+}\right.$ and $\left.\mathrm{Mg}^{2+}\right)$ which indicated good ion balance for samples. A very good correlation between measured Electrical Conductivity (EC) and calculated conductivity $\left(\mathrm{R}^{2}=0.87\right)$ further confirmed good quality of dataset.

\section{Results and Discussion}

\section{$\mathrm{pH}$ variation in snowmelt samples}

The $\mathrm{pH}$ of the snowmelt samples ranged from 5.47 to 7.95 with an average of 6.37 . Approximately, 95\% samples had $\mathrm{pH}$ more than 5.6. The $\mathrm{pH}$ of precipitation in a clean atmosphere is generally 5.6 due to its equilibration with atmospheric $\mathrm{CO}_{2}$ [36]. The snowmelt samples with $\mathrm{pH}$ more than 5.6 indicating inputs of alkaline components at this sampling site, which has been discussed in subsequent sections. Alkaline precipitation is a typical feature of Indian region due to suspended atmospheric dusts rich in calcium carbonate [2]. Similar range of $\mathrm{pH}$ distribution has been reported by many workers in global precipitation (Table 1 ). At this site, only $5 \%$ acidic precipitation has been observed. Results of this site were compared with other sites in Indian region. Satyanarayana et al. [30] have reported $11 \%$ acidic precipitation at Hudegade in ecologically sensitive region of Western Ghats, India. The frequency distribution of $\mathrm{pH}$ of snow samples showed that approx. $17 \%$ samples were acidic at Kothi in north western Himalayan region of India [16]. Very high frequency of acid rain occurrence has been reported over Indian Ocean during INDOEX due to high concentration of non-sea salt sulphate [37]. 


\section{Ionic composition of snowmelt samples}

Table 2 gives statistical parameters of major ions of snowfall. The ion concentration followed the following sequence- $\mathrm{Ca}^{2+}>\mathrm{Cl}^{-}>\mathrm{Na}^{+}$ $>\mathrm{SO}_{4}^{2-}>\mathrm{HCO}_{3}^{-}>\mathrm{NH}_{4}^{+}>\mathrm{NO}_{3}^{-}>\mathrm{Mg}^{2+}>\mathrm{K}^{+}>\mathrm{F}^{-}$(Figure 2). Among cations, the percent concentration followed the sequence $-\mathrm{Ca}^{2+}>\mathrm{Na}^{+}$ $>\mathrm{NH}_{4}^{+}>\mathrm{Mg}^{2+}>\mathrm{K}^{+}$while anions followed the sequence- $\mathrm{Cl}^{-}>\mathrm{SO}_{4}^{2-}>$ $\mathrm{HCO}_{3}^{-}>\mathrm{NO}_{3}^{-}>\mathrm{F}^{-}$.

The most abundant ion was $\mathrm{Ca}^{2+}$, with concentrations ranging from 43 to $111 \mu \mathrm{eq} / \mathrm{L}$. The average concentration of $\mathrm{Ca}^{2+}$ was 87 $\mu \mathrm{eq} / \mathrm{L}$ accounts for approximately $24 \%$ of all ions and $44 \%$ among all cations. We compared snowfall concentration of $\mathrm{Ca}^{2+}$ at this site with global reports. It was observed that the average concentration of $\mathrm{Ca}^{2+}$ at Mukteshwar was higher than Khumbu-Himal [9]. The highest concentration of $\mathrm{Ca}^{2+}$ indicating the dominance of crustal and marine sources which has been discussed in source contribution section. High levels of $\mathrm{Ca}^{2+}$ due to local as well as transported dust have been reported in precipitation $[30,38]$. The suspended soil dust might be significant local source for $\mathrm{Ca}^{2+}$ since the the soil in this region are loosely bound in the earth crust. Since, the site is very fascinating place for tourists attracting its scenic beauty. The ongoing construction activities

\begin{tabular}{|c|c|c|c|}
\hline Sampling site & Country & $\mathbf{p H}$ & Reference \\
\hline Mukteshwar, Uttarakhand & India & $\mathbf{6 . 3 7}$ & Present study \\
\hline Gulmarg, Jammu \& Kashmir & India & $\mathbf{6 . 7 0}$ & {$[31]$} \\
\hline Kothi, Himachal Pradesh & India & $\mathbf{5 . 6 9}$ & {$[16]$} \\
\hline Central and Southern Californis & USA & $\mathbf{5 . 2 0}$ & {$[59]$} \\
\hline Scottish Catchment & Europe & $\mathbf{4 . 2 0}$ & {$[60]$} \\
\hline Larsemann Hills & Antartica & $\mathbf{5 . 7 1}$ & {$[58]$} \\
\hline
\end{tabular}

Table 1: Geographical comparison of $\mathrm{pH}$ of snowmelt samples. especially building resorts to accomodate the maximum number of tourists. Besides this, road dust also contributes $\mathrm{Ca}^{2+}$ in precipitation. These activities are considered as significant sources of $\mathrm{Ca}^{2+}[16,20]$. Very high concentration of $\mathrm{Ca}^{2+}$ due to suspended dust has been reported in indian precipitation [24].

After $\mathrm{Ca}^{2+}$ and $\mathrm{Na}^{+}, \mathrm{NH}_{4}^{+}$ion has been most abundant. $\mathrm{NH}_{4}^{+}$ concentrations ranged from 4 to $52 \mu \mathrm{eq} / \mathrm{L}$. The average concentration of $\mathrm{NH}_{4}{ }^{+}$was recorded as $24 \mu \mathrm{eq} / \mathrm{L}$ which accounted for approximately $7 \%$ of all ions and $12 \%$ among all cations. Very high concentration of $\mathrm{NH}_{4}^{+}$among all cations indicated a significant influence of anthropogenic sources at Mukteshwar. The most important sources of $\mathrm{NH}_{4}^{+}$are agriculture activities, livestock, excreta of human and animal etc. [19,39]. Local people in this region are dependent upon mainly agriculture activities for their livelihood. Due to this region, agriculture activities and livestock might be a significant source of $\mathrm{NH}_{4}^{+}$at this site. Apart from these sources, local people as well as tourists reaching here also might be significant source for $\mathrm{NH}_{4}^{+}$in this region. Singh and coworkers [39] reported that humans are also a significant source of $\mathrm{NH}_{3}$. Since many local people are forced to go in the open field for excretion since they don't have proper toilet facility. Open excreta of human and animal also might be a good source of $\mathrm{NH}_{4}^{+}$at Mukteshwar. Apart from above mentioned sources, some contribution of long range transport can't be ruled out at this site which has not been discussed in this paper.

$\mathrm{SO}_{4}^{2-}$ also had relatively higher concentrations ranging from 2.11 to $99.95 \mu \mathrm{eq} / \mathrm{L}$. The average concentration was observed to be $34.74 \mu \mathrm{eq} / \mathrm{L}$ which accounted for approximately $9 \%$ of all ions and $21 \%$ among all anions. A comparision with other global data, we found that average concentration of $\mathrm{SO}_{4}^{2-}$ at this site was lower than Yulong snow [40] but higher than Mt. Everest [11] and Mt. Logan Massif [41]. Since,
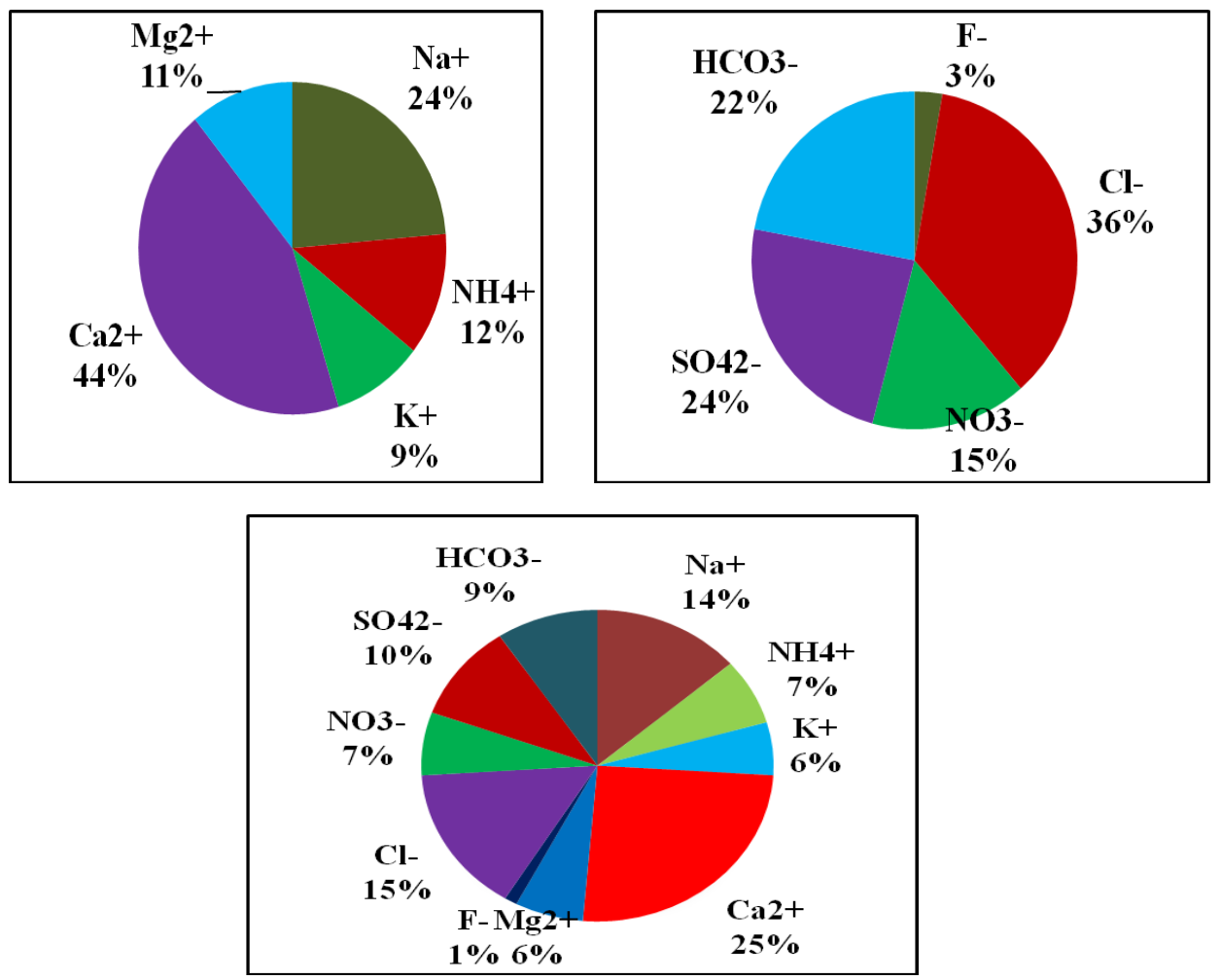

Figure 2: Percent contribution of ions (a) Cations (b) Anions (c) Total ions. 
there is no any industrial activities at this site. Due to this reason, the maximum contribution of $\mathrm{SO}_{4}^{2-}$ might be due to transported $\mathrm{SO}_{4}^{2-}$ from other site in India or transboundary and long range transport $\mathrm{SO}_{4}^{2-}$. Very similar range of $\mathrm{SO}_{4}^{2-}$ concentration has been reported worldwide $[2,26,30,38,42,43]$. High concentration of $\mathrm{SO}_{4}^{2-}$ indicated a significant influence of anthropogenic sources emitting $\mathrm{SO}_{2}$. Among local sources, diesel driven vehicular traffic might be the possible source of $\mathrm{SO}_{4}^{2-}$. Vehicular flow due to increased tourist activities during winter season might be considered as a good source of $\mathrm{SO}_{2}$ at Mukteshwar.

$\mathrm{NO}_{3}$ - was found to have concentrations ranging from 2.8 to 48.8 $\mu \mathrm{eq} / \mathrm{L}$. The average concentration was observed to be $22.6 \mu \mathrm{eq} / \mathrm{L}$ accounts approximately $6 \%$ of total ions and $14 \%$ of total anions. $\mathrm{NO}_{3}$ in snowfall samples might be due to emission of $\mathrm{NO}_{x}$ mainly from vehicular sources which is transformed into the atmosphere which give rise to $\mathrm{NO}_{3}{ }^{-}$in precipitation samples $[44,45]$. Another local source might be biomass burning during winter season to produce heat by local people cannot be ruled out [46]. Apart from local emissions, very high concentration of $\mathrm{NO}_{3}^{-}$might be due to long range transport of $\mathrm{NO}_{x} / \mathrm{NO}_{3}$ - from various air masses approaching at Mukteshwar.

Figure 3 compares $\mathrm{NO}_{3}^{-}$in precipitation samples of Mukteshwar (snowmelt) with urban site, Delhi (rain water) [47]. On an average, it is very clear from the Figure that urban sites had 3 times high $\mathrm{NO}_{3}$ in precipitation. As compared to the size of town and local activities $\mathrm{NO}_{3}$ - values in snowmelt at Mukteshwar are significantly high when we compare the size and the amount of local activities of Delhi city. This indicates that even though Mukteshwar is a remote hilly site, it is significantly affected by long range transport of pollution while most of $\mathrm{NO}_{3}^{-}$in the precipitation of Delhi can be considered as local vehicular contributions. The varying composition of precipitation samples at different sites might be due to differences in local emission, meteorological conditions, methods of sampling, regional and global scale transport of pollutants in relation to air masses, type of sampling site, elevation from sea level etc. [9,24]. In order to understand the possible reason behind the variation of $\mathrm{NO}_{3}^{-}$concentration in precipitation samples, we are comparing our study site i.e. Mukteshwar (rural characteristics) with Delhi city (urban characteristics). Mukteshwar is a small village with no major vehicular pollution except those by tourist activities. Apart from local vehicular emission, significant contribution of $\mathrm{NO}_{3}^{-}$in precipitation at Mukteshwar might be due to transported $\mathrm{NO}_{\mathrm{x}} / \mathrm{NO}_{3}^{-}$from other places within India as well as long range transport of pollutants. Raatikainen and co-workers also observed the transport of pollution from Indo-Gangetic plain to Mukteshwar in Himalayan region of India. Delhi had very high $\mathrm{NO}_{3}$ in precipitation which might be due to a vast increase in vehicular population. In 1994, Delhi had 24,32,295 mobile vehicles which reached to $69,32,706$ in 2010 [48]. This has increased the consumption of petrol by $44.7 \%$. In addition, $\mathrm{NO}_{3}^{-}$might also be contributed by increased number of industrial units. According to Delhi statistics, the number of industries is increased by $39.54 \%$ in Delhi region from 1994-2010 [48].

\section{Source contribution}

In order to find out the contribution of various sources categories, marine and non-marine fractions have been calculated. Further non-marine fraction has been calculated as crustal associated and anthropogenic fractions following the approach as reported by Kulshrestha et al. [49].

Marine contribution: The maximum fraction of sea salt is composed of $\mathrm{Na}^{+}, \mathrm{Cl}^{-}$and $\mathrm{Mg}^{2+}$ with some fraction of $\mathrm{Ca}^{2+}, \mathrm{SO}_{4}{ }^{2-}$ and $\mathrm{K}^{+}$. In order to estimate the marine contribution in snowmelt samples, sea salt ratios were calculated by assuming $\mathrm{Na}^{+}$as a sea salt tracer with marine origin only [50]. The sea salt ratios deviated considerably for all components from standard sea salt ratios (Table 3) indicating significant influence of non-marine contribution. The results showed that $\mathrm{Cl} / \mathrm{Na}^{+}$ratio is very close to sea water ratios indicating its major contribution from marine sources (Table 3). $\mathrm{Mg}^{2+} / \mathrm{Na}^{+}$ratios are slightly higher than the standard sea water ratio reflecting contribution of marine sources with some contribution from non-marine sources. Sodium ratios of $\mathrm{SO}_{4}^{2-}, \mathrm{K}^{+}$and $\mathrm{Ca}^{2+}$ are higher than standard sea water ratios indicating their likely contribution from soil or anthropogenic sources. Elevated ratios of $\mathrm{SO}_{4}^{2-} / \mathrm{Na}^{+}, \mathrm{K}^{+} / \mathrm{Na}^{+}$and $\mathrm{Ca}^{2+} / \mathrm{Na}^{+}$have been reported at various other sites in Indian region [2,26,29].

In order to estimate sea salt fraction (ssf) and non-sea salt fraction (nssf) the following formula were used:

$$
\% \text { ssf }=\frac{100}{E F_{\text {sea water }}}
$$

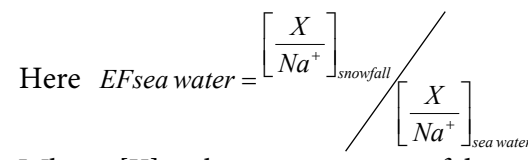

Where, $[\mathrm{X}]$ is the concentration of desired ionic species in ueq/l.

$\%$ nssf $=100-\%$ ssf

The percent contribution of sea salt fraction and non-sea salt fraction of $\mathrm{Cl}^{-}, \mathrm{SO}_{4}^{2-}, \mathrm{K}^{+}, \mathrm{Ca}^{2+}$ and $\mathrm{Mg}^{2+}$ in snowfall samples has been given in Table 3 . It is very clear from the table that the maximum fraction of $\mathrm{SO}_{4}^{2-}, \mathrm{K}^{+}$and $\mathrm{Ca}^{2+}$ originated from non-marine sources. Similar to our results, large fraction of $\mathrm{nssSO}_{4}{ }^{2-}$ and $\mathrm{nssCa}^{2+}$ have been

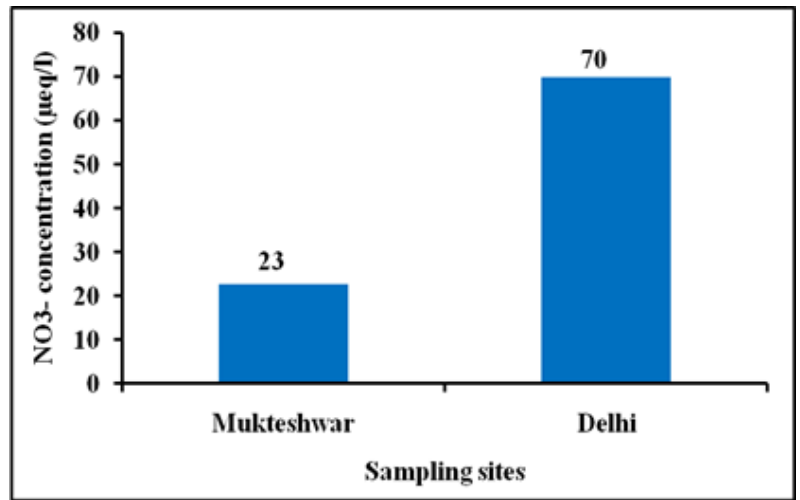

Figure 3: Comparison of $\mathrm{NO}_{3}^{-}$in precipitation at Mukteshwar (nowmelt) and Delhi (rain water). $\mathrm{NO}_{3}^{-}$value of Delhi precipitation has been taken from Singh et al. [50].

\begin{tabular}{|c|c|c|c|}
\hline & Average & Min & Max \\
\hline $\mathbf{p H}$ & 5.47 & 7.95 & 6.37 \\
\hline $\mathbf{E C}$ & 27.6 & 20.9 & 42.5 \\
\hline $\mathbf{N a}^{+}$ & 47 & 22 & 82 \\
\hline $\mathbf{N H}_{4}^{+}$ & 24 & 4 & 52 \\
\hline $\mathbf{K}^{+}$ & 19 & 5 & 42 \\
\hline $\mathbf{C a}^{2+}$ & 87 & 43 & 111 \\
\hline $\mathbf{M g}^{2+}$ & 22 & 6 & 56 \\
\hline $\mathbf{F}^{-}$ & 4 & 1 & 9 \\
\hline $\mathbf{C l}^{-}$ & 52 & 26 & 85 \\
\hline $\mathbf{N O}_{3}^{-}$ & 23 & 10 & 38 \\
\hline $\mathbf{S O}_{4}^{-2}$ & 35 & 13 & 49 \\
\hline $\mathbf{H C O}_{3}^{-}$ & 32 & 5 & 78 \\
\hline
\end{tabular}

Table 2: $\mathrm{pH}, \mathrm{EC}$ and ionic composition ( $\mu \mathrm{eq} / \mathrm{L})$. 


\begin{tabular}{|c|c|c|c|c|c|}
\hline & $\mathbf{C l}^{-}$ & $\mathbf{S O}_{4}{ }^{2-}$ & $\mathbf{K}^{+}$ & $\mathbf{C a}^{2+}$ & $\mathbf{M g}^{2+}$ \\
\hline $\begin{array}{c}\text { Sea water ratios (Keene et al. } \\
\text { 1986) }\end{array}$ & 1.16 & 0.125 & 0.022 & 0.044 & 0.227 \\
\hline Snowmelt ratios & 1.12 & 0.74 & 0.40 & 1.86 & 0.46 \\
\hline EF (sea water) & 0.97 & 5.93 & 18.36 & 42.30 & 2.03 \\
\hline \%ssf & 100 & 17 & 5 & 2 & 49 \\
\hline \%nssf & 0 & 83 & 95 & 98 & 51 \\
\hline
\end{tabular}

Table 3: Sodium ratios of snowmelt and percent sea salt fraction and non sea salt fraction of major ions at Mukteshwar

\begin{tabular}{|c|c|c|c|}
\hline Ions & Marine & $\mathbf{C F}$ & Anthropo \\
\hline $\mathbf{C l}^{-}$ & 100 & 0 & 0 \\
\hline $\mathbf{N O}_{3}{ }^{-}$ & 0 & 12.3 & 87.7 \\
\hline $\mathbf{S O}_{4}{ }^{2-}$ & 16.7 & 22.4 & 60.9 \\
\hline $\mathbf{K}^{+}$ & 5.4 & 94.6 & 0 \\
\hline $\mathbf{C a}^{2+}$ & 2.3 & 97.7 & 0 \\
\hline $\mathbf{M g}^{2+}$ & 48.9 & 51.1 & 0 \\
\hline $\mathbf{N a}^{+}$ & 100 & 0.0 & 0 \\
\hline $\mathbf{N H}_{\mathbf{4}}^{+}$ & 0 & 4.2 & 95.8 \\
\hline $\mathbf{F}^{-}$ & 0 & 1.0 & 99.0 \\
\hline
\end{tabular}

Table 4: Percent contribution of marine, crustal (CF) and anthropogenic fraction (Anthropo) of all ions.

reported at various sites in snow samples [12,31,40,51].

Non-marine contribution: Further, non- marine fraction was differentiated into two categories- i) crustal associated and ii) anthropogenic sources. It is well known that anthropogenic sources are mainly responsible for lowering the $\mathrm{pH}$ of precipitation i.e. enhancing acidity while crustal sources i.e. alkaline species increases the $\mathrm{pH}$ and decrease the acidity of precipitation $[3,52,53]$. The contribution of crustal associated fraction (CF) and anthropogenic fraction (Anthro) of ionic species was calculated by the same approach as it was used by Kulshrestha et al. [49] which is an appropriate approach to explain $\mathrm{pH}$ value in Indian precipitation.

The nss $\mathrm{Ca}^{2+}$ was considered as reference element in snowfall samples in order to determine the crustal associated fraction (CF) of major ions [2]. The percent contribution of CF was calculated by the following formula:

$$
\% C F_{X}=\frac{100}{E F_{\text {soil }}}
$$

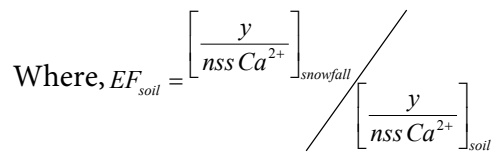

$\mathrm{y}=\left(\mathrm{nss} \mathrm{SO}_{4}^{2-}\right.$, nss $\mathrm{Ca}^{2+}$, nss K $\mathrm{K}^{+}$, nss $\mathrm{Mg}^{2+}, \mathrm{NO}_{3}, \mathrm{NH}_{4}^{+}$and $\left.\mathrm{F}^{-}\right)$in $\mu \mathrm{eq} / \mathrm{L}$.

The percent contribution of Anthro fractions of each ion was calculated by the following formula-

$$
\% \text { Anthro }_{x}=\% n s s_{x}-\% C F_{x}
$$

Using the above mentioned formula, the source characterization for different ions of snowfall has been calculated as given in Table 4 . It is very clear from the table that the maximum contribution of $\mathrm{Ca}^{2+}$ is associated with crustal fraction. The percent contribution of $\mathrm{SO}_{4}^{2-}$, $\mathrm{NH}_{4}^{+}$and $\mathrm{NO}_{3}{ }_{3}^{-}$was the highest in Anthro in comparison to CF. The highest contribution of crustal $\mathrm{Ca}^{2+}$ might be due to contribution from local sources such as local soil, construction activities, road dust etc. as well as long range transport of fine dusts. The significant contribution of long range transport has been reported in snow samples globally
$[7,54]$. Very high percent contribution of Anthro $\mathrm{SO}_{4}^{2-}$ at this site might be due to transported $\mathrm{SO}_{2} / \mathrm{SO}_{4}{ }^{2-}$ mainly since there is no any significant source of $\mathrm{SO}_{2}$ nearby the sampling site. The crustal $\mathrm{SO}_{4}^{2-}$ at this site might be due to reaction of $\mathrm{SO}_{2}$ with $\mathrm{CaCO}_{3}$ rich dust particles forming calcium sulphate $[2,3]$ which is very common in Indian region. The highest contribution of $\mathrm{NH}_{4}^{+}$by anthropogenic sources might be due to significant contribution from local sources like agricultural activities, animal and human excreta, biomass burning, biogenic sources etc. with some contribution due to transported $\mathrm{NH}_{4}^{+}$carried out by various air masses at this site.

Very high fraction of Anthro $\mathrm{NO}_{3}^{-}$might be due to the emissions of $\mathrm{NO}_{\mathrm{x}}$ from fossil fuel combustion and biomass burning. Among local sources, vehicles used by tourist might be the major source of $\mathrm{NO}_{x}$. The significant contribution of $\mathrm{NO}_{3}^{-}$has been reported in air masses due to long range transport of $\mathrm{NOx} / \mathrm{NO}_{3}{ }^{-}$in precipitation samples $[16,30]$.

Average contribution of different sources: The average contribution of different sources viz. marine, crustal and anthropogenic was calculated by the following formula:

Average marine $\%=\frac{\sum X_{\text {ssf }}}{\sum X_{\text {Total }}} \times 100$

Here $\sum X_{\text {sff }}=$ Sum of concentration of all ssf values in each air mass cluster in $\mu$ eq/L.

$\sum \mathrm{X}_{\text {Total }}=$ Sum of concentration of all components in each air mass cluster in $\mu \mathrm{eq} / \mathrm{L}$

Average crustal $\%=\frac{\sum X_{C F}}{\sum X_{\text {Total }}} \times 100$

Here $\sum \mathrm{X}_{\mathrm{CF}}=$ Sum of concentration of all CF values in each air mass cluster in $\mu \mathrm{eq} / \mathrm{L}$.

Average Anthro\%=100-Average marine\%-Average crustal\%

Using the above approach, the average percent contribution of marine, crustal and anthropogenic sources was calculated and given in Figure 4. The order of dominance followed the sequence- Crustal (40\%) >Marine (38\%) >Anthropogenic (22\%). The significant contribution of crustal fraction has been observed in snow samples which might be due to local contribution with long range transport $[15,16]$. After crustal contribution, it was observed that the marine contribution dominated over anthropogenic sources. A very similar kind of observation has been reported in precipitation samples in Indian region [38]. The $\mathrm{pH}$ of snowmelt samples at this site suggesting significant dominance of alkaline species (crustal components) over acidic species (anthropogenic components) since sea salt don't play any important role in deciding $\mathrm{pH}$ of precipitation samples.

\section{Neutralization factor}

It is well known that $\mathrm{NO}_{3}{ }^{-}$and $\mathrm{SO}_{4}{ }^{2-}$ are the major acidic species while nss $\mathrm{Ca}^{2+}$, nss $\mathrm{Mg}^{2+}$ and $\mathrm{NH}_{4}^{+}$are the major alkaline species in precipiation samples. Due to this fact, $\mathrm{nss} \mathrm{Ca}^{2+}$, nss $\mathrm{Mg}^{2+}$ and $\mathrm{NH}_{4}^{+}$are mainly considered for calculation of neutralization factor.

The neutralization factor of these species were calculated by the following formula-

$$
N F_{X i}=\frac{\left[\mathrm{X}_{\mathrm{i}}\right]}{\left[\mathrm{NO}_{3}{ }^{-}+\mathrm{nss} \mathrm{SO}_{4}{ }^{2-}\right]}
$$

Where $\left[\mathrm{X}_{\mathrm{i}}\right]=$ The concentration of desired ionic species i.e. nss $\mathrm{Ca}^{2+}$, nss $\mathrm{Mg}^{2+}$ and $\mathrm{NH}_{4}^{+}$in $\mu \mathrm{eq} / \mathrm{l}$.

Using the above mentioned formula, the neutralization factor of nss $\mathrm{Ca}^{2+}$, nss $\mathrm{Mg}^{2+}$ and $\mathrm{NH}_{4}^{+}$was calculated and are given in Figure 5 . 
Citation: Kumar B, Gupta GP, Singh S, Lone FA, Kulshrestha UC, et al. (2015) Snow Chemistry at Mukteshwar in Central Himalayan Region of India. Mod Chem appl 3: 160. doi:10.4172/2329-6798.1000160

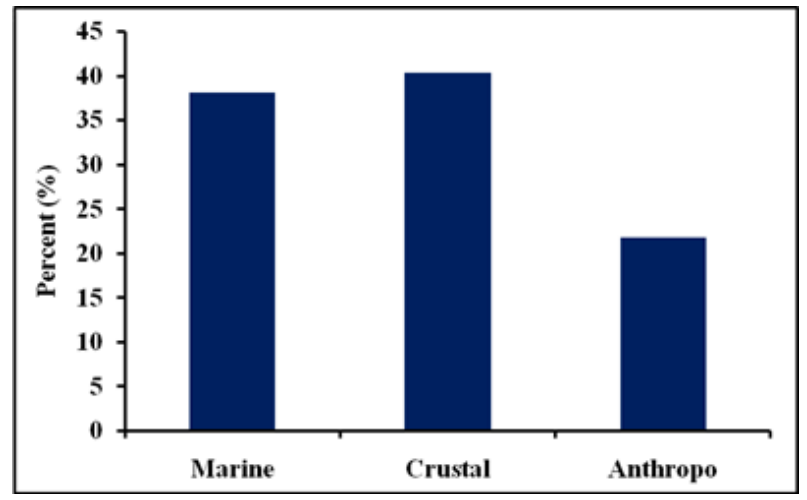

Figure 4: Average contribution of marine, crustal and anthropogenic sources

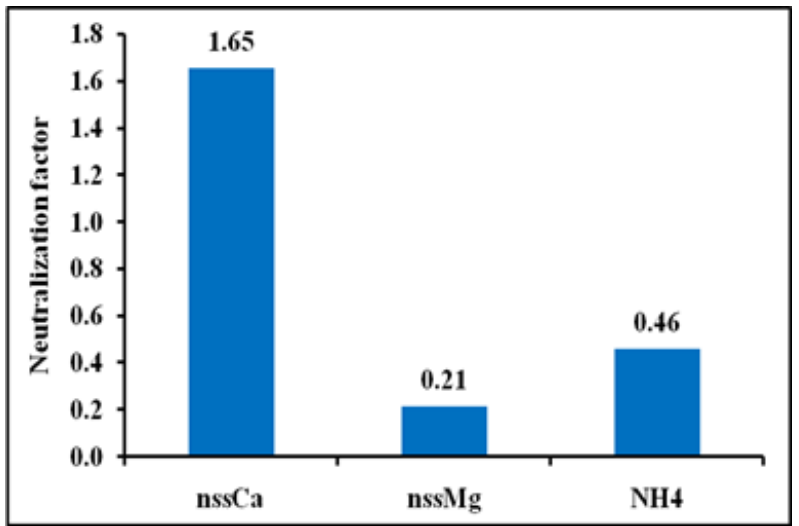

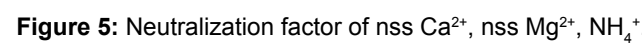

The neutralization factor for these species followed the order- nss $\mathrm{Ca}^{2+}$ $>\mathrm{NH}_{4}^{+}>\mathrm{nss} \mathrm{Mg}^{2+}$.

The maximum neutralization of snowfall acidity occurs by $\mathrm{nssCa}^{2+}$ which might be due to suspended soil dust rich in $\mathrm{CaCO}_{3}$ in Indian atmosphere [29]. These soil dusts might be contributed significantly by long range transport. The importance of transported dust in the neutralization of acidic components in precipitation samples has been observed globally [30,38]. Very high value of neutralization factor for $\mathrm{nssCa}{ }^{2+}$ and $\mathrm{NH}_{4}^{+}$has been reported in precipitation samples globally $[2,30,53,55-60]$.

\section{Conclusion}

The $\mathrm{pH}$ of fresh snowfall collected at Mukteshwar was noticed in the range of 5.47-7.95 with an average of 6.37 which is similar to the $\mathrm{pH}$ of precipitation reported in other studies in this region. This is mainly due to the interferences of crustal sources. Among all ionic species, $\mathrm{Ca}^{2+}$ dominated. $\mathrm{CaCO}_{3}$ rich aerosols are contributed by the suspension of soil, road dusts and construction activities. Scavenging of such aerosols gives rise to high $\mathrm{pH}$ of precipitation due to buffering action. Even at high $\mathrm{SO}_{4}^{2-}$ levels, the $\mathrm{pH}$ is relatively higher as the acidity created by sulphuric acid is buffered by the presence of $\mathrm{Ca}^{2+}$. Relative source contribution to the snowmelt was calculated as crustal $40 \%$, marine $38 \%$ and anthropogenic $22 \%$ at the site. Comparison of $\mathrm{NO}_{3}^{-}$values revealed that precipitation at Delhi is highly influenced by vehicular sources showing very high $\mathrm{NO}_{3}^{-}$as compared to Mukteshwar. Interestingly, in spite of small town having lesser vehicular activities, precipitation at Mukteshwar has relatively high $\mathrm{NO}_{3}^{-}$values which might be due to long range transport of $\mathrm{NO}_{x} / \mathrm{NO}_{3}$.

\section{Acknowledgement}

Financial support received from JNU as CBF, LRE and DST-PURSE grants is gratefully acknowledged. Author Bablu Kumar, Gyan Prakash Gupta and Sudha Singh acknowledge the award of fellowships from UGC. Our sincere thanks to $\mathrm{Mr}$. Kaushal $\mathrm{Ji}$ for his help in collection of snowfall samples.

\section{References}

1. Klimont Z, Smith SJ, Cofala J (2013) The last decade of global anthropogenic sulfur dioxide: 2000-2011 emissions Environ Res Lett 8: 014003.

2. Kulshrestha UC, Kulshrestha MJ, Sekar R, Sastry GSR, Vairamani M (2003) Chemical characteristics of rainwater at an urban site of south-central India. Atmos Environ 37: 3019-3026.

3. Kulshrestha UC (2013) Acid rain. In: Encyclopedia of Environmental Management. Jørgensen SE (editor) Taylor and Francis, Manila Typesetting Company.

4. Andreae MO, Crutzen PJ (1997) Atmospheric aerosols: biogeochemica sources and role in atmospheric chemistry. Science 276: 1052-1058.

5. Ramanathan V, Crutzen PJ, Kiehl JT, Rosenfeld D (2001) Aerosols, climate, and the hydrological cycle. Science 294: 2119-2124.

6. IPCC (2014) Climate Change 2014: Synthesis report. Fifth assessment report (AR5) of the Intergovernmental Panel on Climate Change. Cambridge University Press, Cambridge, United Kingdom and New York, NY, USA.

7. Mayewski PA, Lyons WB, Ahmad N (1983) Chemical composition of a high altitude fresh snowfall in the Ladakh, Himalayas. Geophys Res Lett 10: 105108

8. Wang C, Zhu W, Wang Z, Guicherit R (2000) Rare Earth elements and other metals in atmospheric particulate matter in the western part of the Netherlands. Water Air Soil Pollut 12: 109-118.

9. Marinoni A, Polesello S, Smirraglia C, Valssecchi S (2001) Chemical composition of fresh snow samples from the southern slope of Mt. Everest region (Khumbu-Himal region, Nepal). Atmos Environ 35: 3183-3190.

10. Kang SC, Qin DH, Mayewski PA, Sneed SR, Yao TD (2002) Chemical composition of fresh snow on Xixabangma peak, Central Himalaya, during the summer monsoon season. J Glaciol 48: 337-339.

11. Kang SC, Mayewski PA, Qin DH, Sneed SR, Ren JW, et al. (2004) Seasonal differences in snow chemistry from the vicinity of Mt. Everest, central Himalayas. Atmos Environ 38: 2819-2829.

12. Niu H, He Y, Zhu G, Xin H, Du J, et al. (2013) Environmental implications of the snow chemistry from Mt. Yulong, southeastern Tibetan Plateau. Quat Int 313-314: 168-178.

13. Xu J, Zhang Q, Li X, Ge X, Xiao C, et al. (2013) Dissolved Organic Matte and Inorganic lons in a Central Himalayan Glacier: Insights into Chemical Composition and Atmospheric Sources. Environ Sci Technol 47: 6181-6188.

14. Zhang Y, Xiu G, Wu X, Moore CW, Wang J, et al. (2013) Characterization of mercury concentrations in snow and potential sources, Shanghai, China. Sci Total Environ 449: 434-442.

15. Shrestha AB, Wake CP, Dibb JE, Whitlow SI (2002) Aerosol and Precipitation Chemistry at a Remote Himalayan Site in Nepal. Aerosol Sci Technol 36: 441 456.

16. Kulshrestha UC, Kumar B (2014) Airmass Trajectories and Long Range Transport of Pollutants: Review of Wet Deposition Scenario in South Asia. Adv Meteor 2014: 596041.

17. Rodhe H, Granat L (1984) An evaluation of sulfate in European precipitation 1955-1982. Atmos Environ 18: 2627-2639.

18. Hara $\mathrm{H}$, Akimoto $\mathrm{H}$ (1993) National level variations in precipitation chemistry in Japan. In Proceedings of the International Conference on Regional Environment and Climate Changes in East Asia, Taipei. November 30-December 3, 1993.

19. Galloway JN (1995) Acid deposition: perspectives in time and space. Water Air Soil Poll 85: 15-24.

20. Rahn KA (1976) The chemical composition of the atmospheric aerosol technical report. Graduate School of Oceanography, University of Rhode Island, Kingston

21. Khemani LT (1989) Physical and chemical characteristics of atmospheric 
aerosols. Cheremisionoff PN (editor) Air pollution control Volume 2, Gulf Publishing, USA.

22. Kumar N, Kulshrestha UC, Saxena A, Khare P, Kumari KM, et al. (1993) Effect of anthropogenic formate and acetate level in precipitation at four sites in Agra. Atmos Environ 27B: 87-91.

23. Kulshrestha UC, Sarkar AK, Srivastava SS, Parashar DC (1996) Investigation into atmospheric deposition through precipitation studies at New Delhi (India). Atmos Environ 30: 4149-4154.

24. Kulshrestha UC, Granat L, Engardt M, Rodhe H (2005) Review of precipitation monitoring studies in India a search for regional patterns. Atmos Environ 39: 7403-7419.

25. Safai PD, Rao PSP, Momin GA, Ali K, Chate DM, et al. (2004) Chemical composition of precipitation during 1984-2002 at Pune, India. Atmos Environ 38: $1705-1714$

26. Tiwari S, Kulshrestha UC, Padmanabhamurty B (2007) Monsoon rain chemistry and source apportionment using receptor modeling in and around National Capital Region (NCR) of Delhi, India. Atmos Environ 4: 5595-5604.

27. Mahadeven TN, Negi BS, Meenakshy V (1989) Measurement of element composition of aerosol matter and precipitation from a remote continental site in India. Atmos Environ 23: 869-874

28. Rao PSP, Momin GA, Naik MS, Safai PD, Pillai AG, et al. (1990) Impact of Ca and $\mathrm{SO} 4$ on $\mathrm{pH}$ of rain water in rural environment in India. Indian J Environ Pollut 10: 941-943.

29. Jain M, Kulshrestha UC, Sarkar AK Parashar DC (2000) Influence of crustal aerosols on wet deposition at urban and rural sites in India. Atmos Environ 34: 5129-5137.

30. Satyanarayana J, Reddy Kumar AL, Kulshrestha JM, Kulshrestha CU (2010) Chemical composition of rain water and influence of airmass trajectories at a rural site in an ecological sensitive area of Western Ghats (India). J Atmos Chem 66: 101-116

31. Naik MS, Khemani LT, Momin GA, Rao PS, Safai PD, et al. (1995) Chemical composition of fresh snow from Gulmarg, North India. Environ Pollut 87: 167 171

32. Lone FA, Khan MA, Qureshi N, Kirmani NA, Sidiquee SH, et al. (2010) Environmental chemistry of a rare muddy snowfall occurrence on Alpine zone glaciers of Gulmarg, Kashmir Himalaya, India. Curr World Environ 5: 271-278.

33. American Public Health Association (1998) Standard Methods for the Examination of Water and Wastewater. American Water Works Association, Water Environment Federation.

34. Ayers GP (1995) Some practical aspects of acid deposition measurement Presentation to the Third Expert Meeting on Acid Deposition Monitoring Network in East Asia. 14-16 November 1995, Niigata Prefecture, Japan, pp. 1-20.

35. WMO (1994) Report of the workshop on precipitation chemistry laboratory techniques. In: Mohnen, V., Santroch, J., Vet, R. (Eds.), Hradec Kralove, Czech Republic 17-21 October. WMO Report no 102.

36. Charlson RJ, Rodhe H (1982) Factors controlling the acidity of natura rainwater. Nature 295: 683-695.

37. Kulshrestha UC, Jain M, Mandal TK, Gupta PK, Sarkar AK, et al. (1999) Measurements of acid rain over Indian Ocean and surface measurements of atmospheric aerosols at New Delhi during INDOEX pre-campaigns. Curr Sci 76: $968-972$

38. Budhavant KB, Rao PSP, Safai, PD Ali K (2011) Influence of local sources on rainwater chemistry over Pune region, India. Atmos Res 100: 121-131.

39. Singh S, Kulshrestha UC (2012) Abundance and distribution of gaseous ammonia and particulate ammonium at Delhi, India. Biogeosciences 9: 191 207.

40. Zhu GF, Pu T, He YQ, Shi PJ, Zhang T (2012) Seasonal variations of major ions in fresh snow at Baishui Glacier No. , Yulong Mountain, China. Environ Earth Sci 69: 1-10

41. Yalcin K, Wake CP, Dibb JE, Whitlow SI (2006) Relationships between aeroso and snow chemistry at King Col, Mt. Logan Massif, Yukon, Canada. Atmos Environ 40: 7152-7163.

42. Avila A, Alacron M (1999) Relationship between precipitation chemistry and meteorological situations at a rural site in NE Spain. Atmos Environ 33: 1663-1677.
43. Granat L, Norman M, Leck C, Kulshrestha UC, Rodhe H (2002) Wet scavenging of sulfur compound and other constituents during the Indian Ocean Experiment (INDOEX). J Geophys Res 107: 8025

44. Finlayson-Pitts JB, Pitts JN (1986) Atmospheric Chemistry: Fundamentals and experimental techniques. John Willey \& Sons, USA.

45. Seinfeld JH, Pandis SN (2006) Atmospheric Chemistry and Physics: From Air Pollution to Climate Change (2nd Edition), John Wiley \& Sons, USA.

46. Singh S, Gupta GP, Kumar B, Kulshrestha UC (2014) Comparative study of indoor air pollution using traditional and improved cooking stoves in rural households of Northern India. Energy Sustain Dev 19: 1-6.

47. Singh S, Kumar B, Gupta GP, Kulshrestha, UC (2015) Signatures of increasing energy demand of past two decades as captured in rain water composition and airmass trajectory analysis at Delhi (India). J Energy Environ and Carbon credits 4 .

48. Delhi Statistical Hand Book (2011) Directorate of Economics and Statistics Government of National Capital Territory of Delhi.

49. Kulshrestha UC, Jain M, Saxena AK, Kumar A, Parashar DC (1997) Contribution of sulphate aerosol to the rain water at urban site in India. In proceedings of IGAC international symposium on atmospheric chemistry and future global environment, Nagoya congress center, Nagoya, Japan, 11-13 November, 1997.

50. Keene WC, Pszenny AP, Galloway JN, Hawley ME (1986) Sea-salt corrections and interpretations of constituent ratios in marine precipitation. J Geophys Res 91: $6647-6658$

51. Qin DH, Hou SG, Zhang DQ, Ren JW, Kang SC, et al. (2002) Preliminary results from the chemical records of an $80.4 \mathrm{~m}$ ice core from East Rongbuk Glacier, Qomolangma (Everest), Himalaya. Annals of Glaciology 35: 278-284.

52. Rodhe H, Dentener F, Schulz M (2002) The global distribution of acidifying wet deposition. Environ Sci Technol 36: 4382-4388.

53. Zhang M, Wang S, Wu F, Yuan X, Zhang Y (2007) Chemical composition of wet precipitation and anthropogenic influence at a developing urban site in Southeastern China. Atmos Res 84: 311-322.

54. Liu Y, Geng Z, Hou S (2010) Spatial and seasonal variation of major ions in Himalayan snow and ice: a source consideration. J Asian Earth Sci 37: 195205.

55. Das R, Das SN, Mishra VN (2005) Chemical composition of rainwater and dustfall at Bhubaneswar in the east coast of India. Atmos Environ 39: 5908 5916

56. Calvo Al, Olmo FJ, Lyamani H, Alados-Arboledas L, Castro A, et al. (2010) Chemical Composition of Wet Precipitation at the Background EMEP Station in Víznar (Granada, Spain) (2002-2006). Atmos Res 96: 408-420.

57. Saxena A, Sharma S, Kulshrestha UC, Srivastava SS (1991) Factors affecting alkaline nature of rain water in Agra (India). Environ Pollut 74: 129-138.

58. Budhavant KB, Rao PSP, Safai PD (2014) Chemical Composition of SnowWater and Scavenging Ratios over Costal Antarctica. Aerosol Air Qual Res 14: 666-676.

59. Gunj DW, Hoffmann MR (1990) Field investigation on the snow chemistry in central and southern California-I. Inorganic ions and hydrogen peroxide. Atmos Env 24A: 1661-171.

60. Tranter M, Daveis TD, Abrahams PW, Blackwood I, Brimblecombe P, et al. (1987) Spatial variability in the chemical composition of snowcover in a small, remote, scottish catchment. Atmos Environ 2: 853-862. 